Article

\title{
Turnover intentions and job performance of accountants: The role of religiosity and spiritual intelligence
}

\author{
Wisdom Dordunu ${ }^{1}$, Godfred Matthew Yaw Owusu ${ }^{2 *}$, and Samuel Nana Yaw Simpson ${ }^{3}$ \\ 1 Department of Accounting, University of Ghana Business School, University of Ghana; \\ wizzdords@gmail.com \\ 2 Department of Accounting, University of Ghana Business School, University of Ghana; \\ gmowusu@gmail.com/gmyowusu@ug.edu.gh \\ 3 Department of Accounting, University of Ghana Business School, University of Ghana; \\ snysamuel@gmail.com or snysimpson@ug.edu.gh \\ * Correspondence: gmowusu@gmail.com or gmyowusu@ug.edu.gh
}

Received: 5 December 2019; Accepted: 4 March 2020; Published: 13 March 2020

\begin{abstract}
This paper examined the turnover intentions of accountants practicing with audit firms in Ghana. The study specifically, investigated the factors that influence the intentions of accountants to quit their jobs and further ascertained if the intentions to quit have any implications on the job performance of accountants. A survey method of research was adopted and a set of questionnaires was administered to accountants working with accounting firms certified and approved by the Institute of Chartered Accountants, Ghana (ICAG). The hypothesized relationships of the study were tested using the Partial Least Square-based structural equation modeling technique. The findings of this study demonstrate that organizational commitment, job satisfaction, emotional exhaustion, and religiosity are good predictors of turnover intentions of accountants. Further, our analysis also indicates that turnover intentions impact negatively on job performance of accountants. Our findings have two important implications. First, we highlight the relevance of the spiritual dimension of the determinants of turnover intentions by demonstrating with evidence that the extent of an individual's attachment and commitment to religious values and beliefs have important implications on turnover intentions. Second, while job performance has been found to influence turnover intentions of employees, the evidence provided in this study suggests that turnover intentions are also a good predictor of employees' job performance.
\end{abstract}

Keywords: turnover intentions, job performance, spiritual intelligence, accountants

JEL codes: M40, M12

\section{Introduction}

High employee turnover rate continues to be one of the key challenges that confront most organizations in contemporary times. The growing concern over this phenomenon has been anchored on the fact that it sometimes leads to the loss of some of the most talented and skilled employees within an organization. Indeed, it has been argued that high employee turnover rate leads to loss of valued social and financial capital, affects the morale of remaining employees and also impacts negatively on the reputation of the firm (Jannah, Baridwan, \& Hariadi, 2016). The evidence available in existing studies, however, indicate that employee turnover rate in accounting firms is higher than most of the other professions, and continues to be on the rise in many parts of the world (Chong \& Monroe, 2015; Goldstein, 2014; Owusu et al., 2018). 
It has been established that many accountants usually leave the profession a few years after their engagement and less than $50 \%$ of accounting graduates who join the accountancy profession remain in the profession after three years (Pradana \& Salehudin, 2013; Hiltebeitel \& Leauby, 2001). An inevitable consequence of this menace is that accounting firms have to constantly recruit, train and replace most of their professional and experienced staff year in year out which come at a huge cost to the firm. Besides the cost implications, it has also been argued that a high turnover rate among accountants could result in reduced expertise in accountancy firms and potentially affect the quality of service they provide (Chi et al., 2013; Gertsson et al., 2017). The Financial Reporting Council (FRC) of Britain for instance, maintains that the inability of accountancy firms to retain experienced and skilled staff could have a detrimental effect on the quality of service (FRC, 2006). As a result, studies that seek to explore issues on employee's turnover within the accounting profession have been on the ascendency in recent times.

In particular, most existing studies on employee turnover have focused on the turnover intentions of individuals (the intention to quit the job) rather than the actual turnover with the exception of few notable ones (Chi et al., 2013). Indeed, turnover intentions have often been used as a proxy to measure actual turnover as it is believed to be an important predictor of actual turnover behavior (Aghdasi et al., 2011). The current study builds on this area of research by investigating the dominant factors that influence the turnover intentions of professional accountants. The study adds to the literature on turnover intentions in three important ways.

First, notwithstanding the fact that empirical studies on the determinants of turnover intentions abound, existing studies have largely focused on the factors that affect the 'physical needs' of employees and their resulting effect on turnover intentions. Accordingly, factors such as job satisfaction, job burnout, career development, job commitment, rewards and compensations schemes, etc have often been used to explain the intentions of individuals to quit their job on a consistent basis (Chong \& Monroe, 2015; Gertsson et al., 2017; Zimmerman \& Darnold, 2009).

Thus, even though the human person is composed of both the physical and the spiritual (Anwar \& Osman-gani, 2015), existing studies tend to overlook the spiritual dimension in their analysis. While this trend is not surprising given that studies that deal with human behavior, in general, tend to look at the physical aspect with little attention on the spiritual dimension (Fogarty \& Kalbers, 2006), we argue that these physical factors are by no means exhaustive in predicting the turnover intentions of accountants. Consequently, we develop a framework that encompasses both the physical and spiritual factors to predict the turnover intentions of accountants. While controlling for the effect of the physical factors, we examine whether the extent of an individual's attachment and commitment to religious values and beliefs (religiosity) as well as the ability to assess the meaning, vision and core values of his/her life (Spiritual intelligence) are good predictors of turnover intentions of accountants.

Second, this study also investigates a consequence of turnover intentions by examining its effect on the job performance of accountants. While the effect of job performance on turnover intentions has been established (Zimmerman \& Darnold, 2009), we still do not know whether turnover intentions could also affect job performance despite its theoretical appeal. Thus, we provide new evidence by examining the reverse direction which appears reasonable given that the performance of an accountant could be affected negatively if there is a stronger desire to quit the job.

Third, in terms of context, existing studies on turnover intentions have focused predominantly on developed countries with little attention on countries from the African continent (Chatzoglou, Vraimaki \& Komsiou, 2011). Considering the fact that the African continent has been identified to be the continent that is most challenged in terms of the global demand of accountants (IFAC, 2007), studies that focused on African countries are useful in finding lasting solutions to the challenge of shortages of professionals in Africa. The remaining sections of this paper are organized as follows: we review literature, develop a conceptual framework and hypotheses for the study in the next section. This is followed by the section explaining the methodology of the study. The next section discusses the data analysis and findings with the final section presenting the summary and conclusions of the study. 


\section{Literature Review}

\subsection{The Concept of Employee Turnover and Turnover intentions}

An important function of the Human Resource arm of every organization is to be able to attract, recruit and most importantly retain the core of its competent human capital. According to Rehman (2012), this function is essential for organizational effectiveness. While it is practically inconceivable for any organization to keep all its employees up to the stage of retirement, many serious organizations strive to keep their competent staff as long as they can in order to remain competitive. Retention of employees is indeed recognized to be a critical issue to the growth, expansion, and survival of businesses and hence, the problem of high employee turnover has been a major concern to businesses in general and accounting firms in particular for years.

Employee turnover generally describes the act of an employee separating physically from the immediate employer and relinquishing job responsibilities. The implications of high employee turnover rates are well established in the literature. Studies have shown that high employee turnover rate could affect the quality, consistency, and stability of services provided by businesses, demotivate remaining staff members and may promote a feeling of mistrust among a firm's clientele base (Mor Barak, Nissly \& Levin, 2001; Wallace \& Gaylor, 2012). This is due to the fact that employee turnover is usually associated with loss of invaluable knowledge especially when experienced employees quit. It must be emphasized, however, that the decision to quit is usually preceded by the contemplation to quit by the employee. This has been described as turnover intentions and according to Campbell, Im \& Jisu (2014), it is the cognitive process of thinking about quitting one's job, planning on leaving, or feeling the desire to leave.

Due to the negative effects of employee turnover, it is not surprising that studies on turnover have over the years focused extensively on turnover intentions particularly on the determinants of turnover intentions. According to Lambert \& Paoline (2010), turnover intentions remain the most useful proxy for measuring actual turnover as intentions always precede actual behavior. To date, factors including job satisfaction, job burnout, career development, job commitment, rewards and compensations schemes, etc have been identified by prior studies to be important predictors of the intentions of individuals to quit their job (Chong \& Monroe, 2015; Gertsson et al., 2017; Zimmerman \& Darnold, 2009). In this study, we classify these factors to mean the 'physical factors' that influence the intentions of employees to quit their jobs. Within the framework of this study three factors: job satisfaction, organizational commitment, and emotional exhaustion are used to represent the physical factors. In addition, two constructs: religiosity and spiritual intelligence are used to account for the role of spirituality on turnover intentions of accountants as shown in the conceptual framework for the study in Figure 1.

\subsection{Conceptual Framework and Hypotheses Development}

The conceptual framework that guides the current study is presented in Figure 1. Relying on extant studies, this study posits that organizational commitment, job satisfaction, emotional exhaustion, religiosity, and spiritual intelligence may be good predictors of turnover intentions of accountants. The framework also predicts a negative relationship between turnover intentions and job performance. We argue that similar to the known effect of job performance on turnover intentions (Zimmerman \& Darnold, 2009), employees with higher intentions to quit their job are more likely to underperform on the job. Last our model also proposes that organizational commitment, job satisfaction, emotional exhaustion, religiosity, and spiritual intelligence are related to job performance directly and indirectly through turnover intentions. 
Figure 1. Conceptual framework

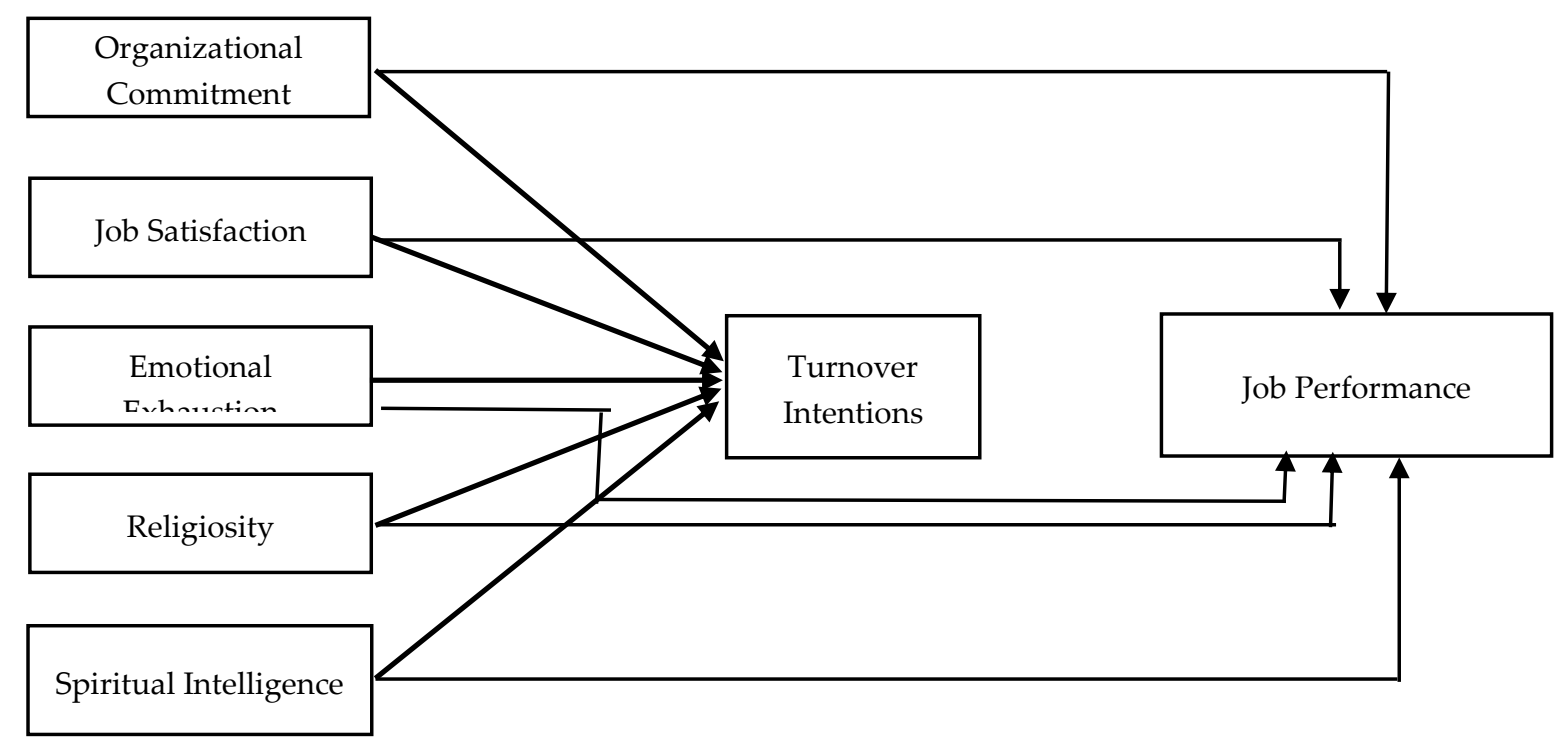

\subsubsection{Organizational Commitment and Turnover Intention}

The term commitment generally refers to the force that binds an individual to a course of action of relevance to one or more targets (Cohen, 2003). On the backdrop of what commitment means, organizational commitment has been defined as an individual's attitude or orientation toward the organization which links or attaches the identity of the person to the organization (Sheldon, 1971, p. 143). The attachment of an individual to an organization has been characterized by Port et al. (1974, p. 604) to consist of at least three factors: (a) a strong belief in and acceptance of the organization's goals and values; (b) a willingness to exert considerable effort on behalf of the organization; (c) a definite desire to maintain organizational membership.

Literature classifies organizational commitment into three distinct components: the Affective, Continuance, and Normative (Bergin, 1994). Affective commitment refers to the sense of belonging or devotion to the organization and this has been in tandem with personal characteristics of the individual including work experience, structures, pay, supervision. Continuance commitment, on the other hand, is the cost of leaving the organization. Anything that is related to this cost either directly or indirectly is the investment that the individual has made in the organization. The normative commitment emerges on the basis of a kind of investment that the organization makes in the life of the individual. The person in question may find it difficult to reciprocate that investment to the organization, hence, it may be compelled to be committed to the organization. In effect, organizational commitment has important implications for the employees themselves, the organization and the society at large.

Regarding the relationship between organizational commitment and turnover intentions, a sense of commitment to an organization by an employee should reduce the intention to leave and vice versa. As explained by Porter et al. (1974), individuals committed to an organization's goals and willingness to sacrifice to achieve those goals would be inclined to remain with the organization in an effort to assist in the realization of such highly valued objectives. A highly committed employee usually has a sense of strong attachment to the organization borne out of acceptance of the values of the organization and hence, strives to remain with the organization. Findings by empirical studies on organizational commitment and turnover intentions nexus however, at best could be described as mixed. While studies (Rahman, Rahman \& Ali, 2015; Schwepker, 2001) found a significant relationship between the two constructs, other studies (Jaramillo, Mulki \& Solomon, 2006; Tnay et al., 2013) report an insignificant relationship between organizational commitment and turnover intentions. Notwithstanding the seemingly divergent views, this study hypothesizes that;

Hypothesis 1: Organizational commitment and turnover intention are inversely related. 


\subsubsection{Job satisfaction and turnover intentions}

Job satisfaction is a measure of an individual's attitude (be it favorable or unfavorable) and the feelings people have about their work (Armstrong, 2006). It is an appraisal of an individual's job or job experiences over time (Dong, et al., 2012). Generally, an individual is said to be satisfied with the job if he finds it pleasurable or finds meaning in the work that he does. In terms of operationalization, Liu et al. (2012) argue that job satisfaction should not be defined as a static variable but rather as a dynamic variable that reflects changes over time. Thus, an employee's job satisfaction according to Liu et al. (2012) reflects the trend of his or her summary job satisfaction perceptions over time and hence, has been identified to be a useful predictor of turnover intentions and actual turnover of employees.

The conventional wisdom is that employees with higher levels of job satisfaction will usually have a lower intention to quit their jobs. As explained by Ijigu (2015), the desire to work in the long-term may be dependent on how satisfied an employee is with the job. Empirically, several studies (Lim, Loo, \& Lee, 2017; Ramalho Luz, Luiz de Paula, \& de Oliveira, 2018; Yücel, 2012) have provided results consistent with the fact that job satisfaction is negatively associated with the turnover intentions of employees. By implication, employees who are satisfied with their job may experience reduced turnover intentions while those who are less satisfied with their job may experience increased turnover intentions.

This study, therefore, hypothesizes that:

H2: A negative relationship exists between job satisfaction and turnover intentions.

\subsubsection{Emotional Exhaustion and Turnover Intention}

Emotional exhaustion is the feeling of being emotionally drained or exhausted by a person's work usually as a result of an increase in the demand for work activities. It is the first aspect that can be recognized when a person experiences burnout and generally considered to be the most visible of the three symptoms characterizing the concept of burnout (Maslach et al., 2001). Thus, among the three concepts characterizing job burnout (emotional exhaustion, depersonalization, and reduced personal accomplishment), emotional exhaustion is by far the most pervasive. This in part explains why emotional exhaustion has received intense research attention compared with the other two aspects of job burnout.

The state of being emotionally drained has been linked with a number of negative outcomes including turnover intentions. Babakus, Yavasb\&Karatepe (2008) for instance, argue that employees who feel drained and overwhelmed by their work and feel they do not have the capacity to cope with emotional exhaustion, display higher propensities to leave their organizations. This tendency is expected given that employees who are emotionally exhausted usually feel as though they lack adaptive resources to perform their job and hence, cannot give any more to their job (Halbesleben \& Buckley, 2004). The tendency to quit when emotionally exhausted has received empirical support from existing studies. Babakus et al. (2008); Ducharme, Knudsen \& Roman (2007) all found emotional exhaustion to be positive and significantly associated with turnover intentions.

This study, therefore, hypothesizes that:

H3: Emotional exhaustion is positively related to turnover intentions.

\subsubsection{Religiosity and turnover intentions}

Religiosity is a measure of an individual's association with and commitment to the ethics and principles of religion. Inherent in this definition is the integration of religious values by the individual in all spheres of life. As a concept, religiosity has been found to impact on people's lives (Sauerwein, 2017; Purnamasari \& Amaliah, 2015) and has also been linked with a number of workplace behaviors (McGhee \& Grant, 2008). The argument is that religious beliefs could have important implications on employees' behavior and productivity at the workplace. There is a dearth of the empirical literature on the influence of religiosity on negative work behavior like turnover intentions. 
In terms of the relationship between religiosity and turnover intentions, the distinction has often been made between intrinsic religiosity and extrinsic religiosity. Whereas the intrinsic religious person sees religion as part of him and his actions and decisions are influenced by his religiosity (Weaver \& Agle, 2002), the extrinsic religious person sees religion as an end in itself and what benefits to be derived from association with religion. The expectation is that intrinsic religiosity should exert a positive influence on an individual's values and promotes good conduct. Accordingly, Olowookere (2016) argues that employees who are intrinsically religious would have lower turnover intentions compared to extrinsically religious employees. However, other studies have pointed out that intrinsic religious employees may not respond with higher levels of citizenship behavior oriented toward the organization when working in an environment they perceive to be violating their belief systems (Kutcher, Bragger, Rodriguez-Srednicki \& Masco, 2010). Thus, the turnover intentions of an intrinsically religious person may be higher if the prevailing working conditions are not in sync with his religious beliefs and values.

Notwithstanding the conceptual differences for the religiosity construct, some studies (Olowookere, 2016) have provided evidence that suggests religiosity has an inverse relationship with turnover intentions. Zafar et al. (2012) however, report a positive relationship between religiosity and turnover intentions, while Hassan, et al (2015) found that no significant relationship between religiosity and turnover intentions.

\section{H4: Religiosity is negatively related to turnover intentions.}

\subsubsection{Spiritual Intelligence and Turnover intentions}

Spirituality involves the search by individuals to fulfill their potential for greater meaning and life purpose in their work (Neck and Milliman, 1994). It is believed that individuals are born with spiritual capacities that give meaning and purpose to life (Wolman, 2001). Spiritual intelligence is concerned with the inner life of mind and spirit and its relationship to being in the world (Vaughan, 2002). Being spiritually intelligent according to Vaughan (2002) is a reflection of how deep an individual is in understanding existential questions and insight into multiple levels of consciousness.

Seligman (2002) highlights the importance of being spiritually intelligent and concludes that spiritually intelligent people are often healthier physically and spiritually, modest and committed to hard work. Again, extant studies have found a strong positive connection between spiritual intelligence and job satisfaction (Koražija, Žižek, \& Mumel, 2016) and also organizational commitment (Amin Mohamed, Wisnieski, Askar, \& Syed, 2004). These studies argue that spiritually intelligent employees usually find a sense of satisfaction with their job and also the commitment of an individual to the organization and work increases when the spiritual dimension of that individual's personality is stronger. To the extent that a spiritually intelligent person finds satisfaction with the job and exhibits a high sense of commitment to an organization, the motivation to quit will below.

Again, it has been suggested that spiritually intelligent employees are more consistent with themselves, happier, and more deeply integrated and harmonious (George, 2006). Such individuals according to George (2006) have a clear sense of identity, are able to discern the real meaning of events and circumstances and make work meaningful. This presupposes that a spiritually intelligent person adjusts and accommodates situations better and strives to make a meaningful impact in any situation. The motivation to quit an organization will, therefore, below for spiritually intelligent employees.

Thus, we hypothesize that:

H5: An inverse relationship exists between spiritual intelligence and turnover intentions.

\subsubsection{Turnover Intention and Job Performance}

The attainment of organizational goals depends substantially on the performance of its workforce. The performance of employees has often been measured with proxies such as time management, leadership skills, and efficiency. In literature, job performance has been found to impact on turnover intentions of workers. Zimmerman \& Darnold (2009) for instance found job performance to be strongly associated with turnover intentions (both directly and indirectly). This association has predominantly 
been explained from the perspective of the Expectancy Theory which proposes that an individual will behave or act in a certain way because they are motivated to select a specific behavior over others due to what they expect the result of that selected behavior will be.

On the basis of this theory, the performance of employees has often been linked with some expectations; be it good or bad. With regards to the turnover intentions and performance nexus, the argument has been that employees who perform poorly during appraisals may have the intention to quit when they suspect such negative feedback could result in undesirable outcomes including being fired by their employer. The fear of such undesirable outcomes according to Zimmerman \& Darnold (2009) may lead them to consider leaving their organizations rather than face unpleasant and potentially psychologically harmful circumstances. We argue based on this established relationship that when the intentions to quit are high, job performance could also be affected negatively. The explanation is that employees with high turnover intentions are less likely to concentrate fully on the job as they may have divided attention which could affect performance. Moreover, when the intentions to quit is high, the focus, commitment, and satisfaction derived from the job will be low which will affect performance on the job negatively.

Thus, we hypothesize that:

H6: An inverse relationship exists between turnover intentions and job performance.

\section{Methods}

\subsection{Design, research instrument, and data collection}

The survey method of research was used with the questionnaire being the principal method of data collection. The questionnaires were developed and administered to the respondents (accountants working with accounting firms in Ghana) after explaining to them the purpose of carrying out the study. The questionnaire had two principal sections with the first section containing information on the demographic characteristics of the respondents. The second part sought respondents' views on the indicators used to measure the key constructs of the study (Turnover intention, Religiosity, Spiritual intelligence, Emotional exhaustion, Job satisfaction, Organizational commitment, job performance).

The turnover intention was measured by adapting the scale developed by Walsh et al., (1985). Religiosity scale was adapted from the works of Ashmos \& Duchon (2000), while Spiritual intelligence was measured using the instrument developed by King (2008). Job satisfaction was measured using a scale developed by Hoppock (1935) and emotional exhaustion was measured using the instrument developed by Maslach and Jackson (1986). Organizational commitment was measured using the instrument developed by Mowday et al. (1974) while Job performance was measured using the scale developed by Patterson (1990). Each construct was measured on a Likert scale with anchors ranging from one to seven. Details of the specific indicators used are provided in Table 2.

\section{ANALYSIS AND RESULTS}

\subsection{Respondents}

This study was conducted with some selected accountants working with the 225 accounting firms that have been certified and approved by the Institute of Chartered Accountants, Ghana (ICAG) as of December 2015. The ICAG is the mandatory body per the constitution of Ghana that regulates the accounting profession. The institute is responsible for conducting qualifying examinations for professional accountants and issuing licenses to accounting firms for public practice. Practicing firms in good standing with the institute have been categorized into five (5) divisions based their revenue and size that as A1, A, B1, B, C, and D. A total of 500 questionnaires were self-administered to the respondent group across the five divisions between February and April 2018. 392 questionnaires were duly received but 55 were excluded from the final analysis as respondents failed to answer most of the questions. Of the 337 respondents included in the final analysis, 197 representing 58.5\% were males with 140 being females. The majority of the respondents fall within the youthful age bracket of 20-39 
which cumulatively accounted for $86.9 \%$ of the total respondents. $72.1 \%$ of the respondents were Christians with $24.6 \%$ being Muslims which confirms the dominance of these two religions in Ghana as documented in the 2010 Housing and Population census of Ghana. There was almost an equal distribution of the respondents across the various categories of firms an indication that the sample distribution of the respondents was fairly balanced. Details of the essential characteristics of the respondents are provided in Table 1.

Table 1. Demographic Characteristics of Respondents

\begin{tabular}{cccc}
\hline Demographics & & Frequency $(\mathrm{n}=337)$ & Percentage $(\%)$ \\
\hline Gender & Male & 197 & 58.5 \\
Age & Female & 140 & 41.5 \\
& $20-24$ & 70 & 20.8 \\
& $25-29$ & 93 & 27.6 \\
& $30-34$ & 81 & 24.0 \\
& $35-39$ & 49 & 14.5 \\
Religious Affiliation & 40 and above & 44 & 13.1 \\
& Christianity & 243 & 72.1 \\
& Moslem & 83 & 24.6 \\
& African Traditional & 4 & 1.19 \\
& Religion & & \\
Marital Status & Atheist & 6 & 1.78 \\
& Others & 1 & 0.3 \\
Bachelor's Degree & Single & 180 & 53.4 \\
& Married & 157 & 46.6 \\
& None & 72 & 21.4 \\
Professional & Accounting & 181 & 53.7 \\
Qualification & Non- Accounting & 84 & 24.9 \\
& ICA (GH) & 193 & 57.27 \\
& & & \\
Category of Firm & ACCA & 117 & 34.72 \\
& CIMA & 27 & 8.01 \\
& A1 & 71 & 21.1 \\
& A & 79 & 23.4 \\
& B1 & 92 & 27.3 \\
& B & 47 & 13.9 \\
& C & 20 & 5.9 \\
& D & 28 & 8.3 \\
\hline & & &
\end{tabular}

\subsection{Descriptive statistics of constructs}

The views of the respondents on the various indicators used to measure the study constructs were ascertained descriptively using the means and standard deviation. Table 2 presents details of the respondents' views on the various constructs for the study. As shown in Table 2, the average mean for the constructs ranged between 3.54 and 5.97, an indication that the respondents generally rated the indicators of the various constructs highly. 
Table 2. Descriptive statistics of study constructs

\begin{tabular}{|c|c|c|c|}
\hline Code & Constructs & Mean & $\begin{array}{l}\text { STD. } \\
\text { DEV. }\end{array}$ \\
\hline Turnover Intention & & 3.54 & 2.190 \\
\hline TI1 & $\begin{array}{l}\text { I am starting to ask my friends about other job } \\
\text { possibilities }\end{array}$ & 3.62 & 2.183 \\
\hline TI2 & I am thinking about quitting my job & 3.44 & 2.118 \\
\hline TI3 & I intend to leave this company within the next 6 months & 3.37 & 2.151 \\
\hline TI4 & $\begin{array}{l}\text { I often look to see if accounting positions in other firms } \\
\text { are open }\end{array}$ & 3.66 & 2.203 \\
\hline TI5 & $\begin{array}{l}\text { I am thinking about contacting a recruiter about other job } \\
\text { possibilities }\end{array}$ & 3.59 & 2.299 \\
\hline Organizational & & 4.59 & 1.59 \\
\hline \multicolumn{4}{|l|}{ Commitment } \\
\hline OC1 & $\begin{array}{l}\text { I am willing to put in a great deal of effort beyond what } \\
\text { is normally expected in order to help this organization be } \\
\text { successful. }\end{array}$ & 5.26 & 1.963 \\
\hline OC2 & $\begin{array}{l}\text { I talk about this organization to my friends as a great } \\
\text { organization to work for. }\end{array}$ & 4.98 & 1.749 \\
\hline OC3 & I do not feel loyal to this organization. & 3.48 & 2.248 \\
\hline OC4 & $\begin{array}{l}\text { I would accept almost any type of job assignment in } \\
\text { order to keep working for this organization. }\end{array}$ & 4.51 & 1.979 \\
\hline OC5 & $\begin{array}{l}\text { I find that my values and the organization's values are } \\
\text { very similar. }\end{array}$ & 4.92 & 1.773 \\
\hline OC6 & $\begin{array}{l}\text { I am proud to tell others that I am part of this } \\
\text { organization. }\end{array}$ & 5.41 & 1.709 \\
\hline OC7 & $\begin{array}{l}\text { I could just as well be working for a different } \\
\text { organization as long as the type of work was similar. }\end{array}$ & 4.51 & 2.000 \\
\hline OC8 & $\begin{array}{l}\text { This organization really inspires the very best in me in } \\
\text { the way of job performance. }\end{array}$ & 5.04 & 1.720 \\
\hline OC9 & $\begin{array}{l}\text { It would take very little change in my present } \\
\text { circumstances to cause me to leave this organization. }\end{array}$ & 4.29 & 1.888 \\
\hline OC10 & $\begin{array}{l}\text { I am extremely glad that I chose this organization to } \\
\text { work for, over others I was considering at the time I } \\
\text { joined. }\end{array}$ & 4.91 & 1.886 \\
\hline OC11 & $\begin{array}{l}\text { There's not too much to be gained by sticking with this } \\
\text { organization indefinitely. }\end{array}$ & 3.99 & 2.062 \\
\hline OC12 & $\begin{array}{l}\text { Often, I find it difficult to agree with this organization's } \\
\text { policies. }\end{array}$ & 4.06 & 2.132 \\
\hline OC13 & $\begin{array}{l}\text { I really care about the future prospects of this } \\
\text { organization. }\end{array}$ & 5.29 & 1.763 \\
\hline OC14 & $\begin{array}{l}\text { For me, this is the best of all possible organizations to } \\
\text { work for. }\end{array}$ & 4.59 & 2.054 \\
\hline OC15 & $\begin{array}{l}\text { Deciding to work for this organization was a definite } \\
\text { mistake on my part. }\end{array}$ & 3.63 & 2.368 \\
\hline Job Satisfaction & & 4.56 & 1.990 \\
\hline JS1 & How satisfied are you with your job? & 4.85 & 2.006 \\
\hline JS2 & How well do you like your job? & 4.94 & 1.808 \\
\hline JS3 & How do you feel about changing your job & 4.12 & 2.106 \\
\hline JS4 & $\begin{array}{l}\text { How often do you compare yourself with other people in } \\
\text { the same job? }\end{array}$ & 4.34 & 2.055 \\
\hline Religiosity & & 3.83 & 1.99 \\
\hline $\mathrm{R} 1$ & My spirit is energized by my work & 3.64 & 2.049 \\
\hline
\end{tabular}


Spiritual Intelligence
The work I do is connected to what I believe is important in life.

My work adds personal meaning to my life. I feel part of a community at work.

I feel there is a sense of being part of a family in my work environment.

I feel positive about the values of my organization.

My current organization cares about all of its employees.

I have often questioned or pondered the nature of reality.

I recognize aspects of myself that are deeper than my physical body.

I have spent time contemplating the purpose or reason for my existence.

I am able to enter higher states of consciousness or awareness.

I am able to deeply contemplate what happens after death.

It is difficult for me to sense anything other than the physical and material.

My ability to find meaning and purpose in life helps me adapt to stressful situations.

I can control when I enter higher states of consciousness or awareness.

I have developed my own theories about such things as life, death, reality, and existence.

I am aware of a deeper connection between myself and other people.

I am able to define a purpose or reason for my life.

I am able to move freely between levels of consciousness or awareness.

I frequently contemplate the meaning of events in my life.

I define myself by my deeper, non-physical self. When I experience a failure, I am still able to find meaning in it.

I often see issues and choices more clearly while in higher states of consciousness/awareness.

I have often contemplated the relationship between human beings and the rest of the universe.

I am highly aware of the nonmaterial aspects of life.

I am able to make decisions according to my purpose in life.

I recognize qualities in people who are more meaningful than their bodies, personality, or emotions.

I have deeply contemplated whether or not there is some greater power or force (e.g., god, goddess, divine being, higher energy, etc.).

Recognizing the nonmaterial aspects of life helps me feel centered.

I am able to find meaning and purpose in my everyday experiences. 
SI24

Emotional Exhaustion

EE1

EE2

EE3

EE4

EE5

Job Performance

JP1

JP2

JP3

JP4

JP5

JP6

JP7

JP8

JP9

JP10

JP11

JP12

JP13
I have developed my own techniques for entering higher states of consciousness or awareness.

I feel emotionally drained from my work

I feel used up at the end of the workday

I feel fatigued when I get up in the morning and have to face another day on the job

Working with people all day is really a strain for me

I feel like giving up on my job

I adhere to the official regulations and administrative principles

I feel responsible for the task I have undertaken and I am in charge of its consequences

I do my job with proper care and concern and I try to perform it with an optimal quality

I pursue the task I have undertaken so that the results are gotten and the confidence is gained

I am very strict with my job, value it greatly and resolve

$$
\text { its problems }
$$

I interact with clients and applicants respectfully and try

$$
\text { to solve their problems }
$$

In case of emergency or humanitarian assistance, I reveal

$$
\text { devotion and self-sacrifice }
$$

I make an attempt to improve my professional

$$
\text { knowledge }
$$

I accept my mistakes

I try to keep the secrets of my job

I try to transfer my professional information to others

I avoid wasting time and taking unnecessary measures

I look after my job equipment and use them economically.
5.05

1.820

3.77

2.110

3.83

2.107

3.85

2.027

3.99

2.038

3.50

2.107

3.66

2.260

5.97

1.370

5.84

1.558

5.93

1.378

6.01

1.346

6.02

5.88

5.93

1.414

5.91

1.375

6.13

1.203

6.07

1.302

5.96

1.489

5.69

1.577

$6.01 \quad 1.299$

6.22

\subsection{Data analyses}

In this study, we employ the Structural equation modeling (SEM) technique to analyze the predicted relationship among the study constructs. SEM-based techniques are particularly useful in evaluating measurement models and structural paths involving multiple dependent variables, latent constructs based on multi-item indicator variables and also facilitates the assessment of both direct and indirect relationships between independent and dependent variables simultaneously (Astrachan, Patel, \&Wanzenried, 2014). The partial least squares SEM (PLS-SEM) was employed in this study.

\subsection{SEM analysis}

The SEM-based analysis begins with an assessment of the measurement model aimed at achieving an adequate level of construct validity. Assessment of the measurement model was done using the internal consistency, indicator reliability, convergent validity, and discriminant validity tests. The indicator reliability was assessed using the indicator loadings. While indicator loadings of 0.70 and above is recommended, loadings of 0.4 and above is deemed appropriate if all other diagnostic tests are good (Hair, Babin, Anderson, \& Rolph, 2010). Based on this criterion, indicators with loadings less than 0.4 were deleted from their respective construct. The final model showing the indicators included in the structural analysis with their respective loadings is as shown in Figure 1. 
Figure 2. Path Diagram of the Structural Model

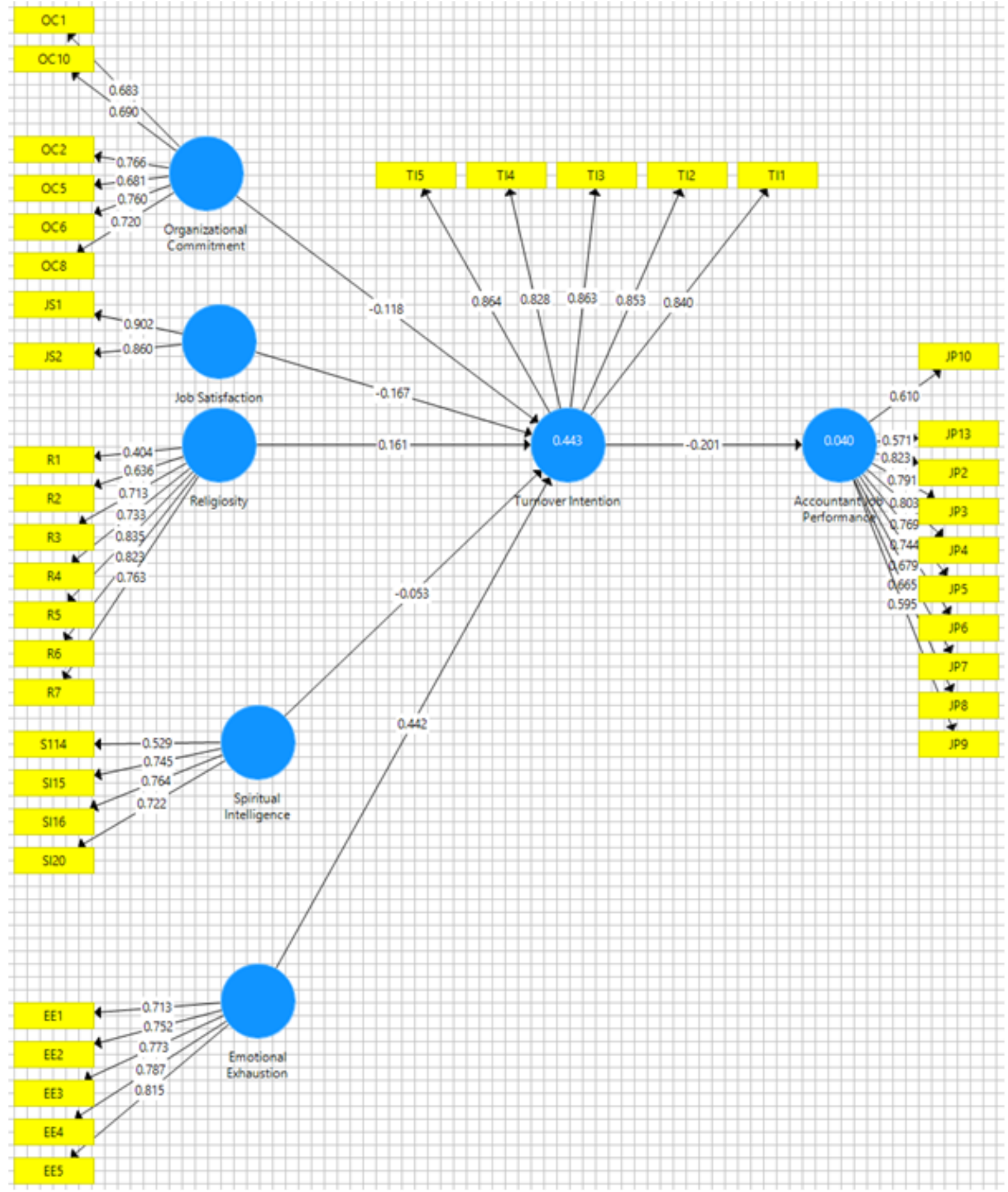

\subsection{Reliability and validity tests}

The reliability of the constructs was assessed by examining both the Cronbach alpha and the composite reliability scores. Results, as shown in Table 3, indicate adequate reliability as the Cronbach alpha and the composite reliability scores for each construct exceeded the recommended threshold of 0.70 (Fornell \& Larcker, 1981; Nunnally, 1978). The validity of the constructs was also assessed using the convergent and discriminant tests. Convergent validity measures the degree to which the various indicators of a construct correlate with one another and was assessed by the average variance extracted (AVE). An AVE score of at least 0.5 is recommended which means that a construct should be able to explain more than half of the variance of its indicators (Hair, Hult, Ringle \& Sarstedt, 2013). The AVE 
scores as shown in Table 3 demonstrate that all the constructs met the recommended minimum threshold.

Discriminant validity test which shows whether the indicators of study constructs are distinct from each other in the path model was conducted using the Fornell-Larcker criterion (Fornell \& Larcker, 1981) which assumes that a construct shares more variance with its own indicators than with any of the other study construct. It is recommended that the square root of the AVE of a particular construct should be higher than the correlation among the other constructs in order for discriminant validity to be assured. Results, as shown in Table 4, indicate that all the constructs are valid as the square root of the AVE scores for the constructs given in italics along the diagonals were greater than the cross-correlations of the constructs,

Table 3. Cronbach Alpha (CA), Composite Reliability (CR) and Average Variance Extracted (AVE)

\begin{tabular}{cccc}
\hline & CA & CR & AVE \\
\hline Job Performance & 0.895 & 0.909 & 0.505 \\
Emotional Exhaustion & 0.830 & 0.878 & 0.591 \\
Job Satisfaction & 0.715 & 0.874 & 0.777 \\
Organizational & 0.811 & 0.864 & 0.515 \\
Commitment & & & \\
Religiosity & 0.835 & 0.875 & 0.515 \\
Spiritual Intelligence & 0.675 & 0.787 & 0.510 \\
Turnover Intention & 0.904 & 0.929 & 0.722 \\
\hline
\end{tabular}

Table 4. Discriminant validity

\begin{tabular}{cccccccc}
\hline & JP & EE & JS & OC & RE & SI & TI \\
\hline JP & 0.711 & & & & & & \\
EE & -0.272 & 0.769 & & & & & \\
JS & 0.194 & -0.284 & 0.881 & & & & \\
OC & 0.447 & -0.333 & 0.478 & 0.718 & & & \\
RE & -0.236 & 0.336 & -0.150 & -0.310 & 0.714 & & 0.697 \\
SI & 0.239 & -0.084 & 0.158 & 0.435 & 0.071 & -0.180 & 0.850 \\
TI & -0.201 & 0.587 & -0.381 & -0.418 & 0.375 & \\
\hline
\end{tabular}

Note: JP represents Job performance; EE represents Emotional exhaustion; JS represents Job satisfaction; OC represents Organizational Commitment; RE represents Religiosity; SI represents Spiritual intelligence and TI represents Turnover intention.

\subsection{Discussion of results}

The structural model results as presented in Table 5 suggest that $44.3 \%$ of the variance in Turnover intention of accountants is explained by the five exogenous constructs (Emotional exhaustion, Job satisfaction, Organizational Commitment, Religiosity, and Spiritual intelligence) while Turnover intention explains $4 \%$ of the variance in the endogenous construct Job Performance. The predictive relevance of the model was assessed by adopting Hair et al. (2014) blindfolding rules. With a crossvalidated redundancy $(\mathrm{Q} 2)$ values of both endogenous constructs exceeding zero as shown in Table 5, the predictive relevance of the model is considered to be satisfactory.

The results as shown in Table 6 show a negative and statistically significant relationship between organizational commitment and turnover intention of the accountant $(\beta=-0.118$, and $p$-value $=0.060)$. By implication, when the commitment of an individual towards his/her immediate organization is high the intention to leave the organization is generally low. Empirically, findings in most existing studies (Jannah, Baridwan, \& Hariadi, 2016; Aydogdu, 2011, Tarigan \& Ariani, 2015) demonstrate that a committed worker is more likely to stay put with his immediate organization even when presented with better opportunities in other organizations. This finding thus, confirms the stated hypothesis (HI) 
and the assertion that organizational commitment is an important predictor of employees' turnover intentions.

Table 5. $\mathrm{Q}^{2}$ and $\mathrm{R}^{2}$

\begin{tabular}{ccc}
\hline Constructs & $\mathbf{Q}^{\mathbf{2}}$ (1-SSE/SSO) & $\mathbf{R}^{\mathbf{2}}$ \\
\hline Job Performance & 0.015 & 0.04 \\
Turnover Intention & 0.296 & 0.443 \\
\hline
\end{tabular}

The relationship between job satisfaction and turnover intention also yielded a negative and highly significant relationship $(\beta=-0.167$, and $\mathrm{p}$ - value $=0.005)$, an indication that when satisfied with the job, the intention to quit is usually low. This means that the intention of an employee to quit the organization will be low when there is a feeling of contentment or a sense of accomplishment from the job. The extent to which an employee likes the job or individual aspect of it is, therefore, an important determinant of the intention to continue to work with the organization or to quit. An important way of maintaining long term working relationship with employees of accounting firms is, therefore, to ensure that they get the desired level of satisfaction with their work. Several empirical studies (Yücel, 2012; Jannah et al., 2016; Dole \& Schroeder 2001; Medina, 2012) have reported results consistent with the fact that job satisfaction has important implications on the turnover intentions of employees. This finding, therefore, supports the predicted hypothesis (H2).

Table 6. Results (direct effect)

\begin{tabular}{ccccc}
\hline Hypotheses & Path & $\begin{array}{c}\text { Standard } \\
\text { Coefficient }\end{array}$ & (P-value) & Remarks \\
\hline H1 & Organizational commitment->Turnover & -0.118 & $0.060^{*}$ & Accepted \\
& $\quad$ Intention & & \\
H2 & Job Satisfaction->Turnover Intention & -0.167 & $0.005^{* * *}$ & Accepted \\
H3 & Religiosity->Turnover Intention & 0.161 & $0.009^{* * *}$ & Accepted \\
H4 & Spiritual Intelligence->Turnover Intention & -0.053 & 0.278 & Not Accepted \\
H5 & Emotional Exhaustion->Turnover Intention & 0.442 & $0.000^{* * *}$ & Accepted \\
H6 & Turnover Intention->Accountant Job & -0.201 & $0.000^{* * *}$ & Accepted \\
& Performance & & & \\
\hline
\end{tabular}

Significance level: ${ }^{* *} 1 \% ;{ }^{* *} \% ;{ }^{*} 10 \%$. The Table shows the path coefficients of the various relationships and Pvalue.

Test of the relationship between religiosity and turnover intention, on the other hand, suggests the existence of a positive relationship between the two constructs $(\beta=0.161$ and $p$ - value $=0.009)$. From the literature, religiosity has been conceptualized to mean an individual's association with and commitment to the ethics and principles of religion and has been acknowledged to be an important influencer of behavior, perception and decision making of employees (Mohklis, 2006; Ferreira Vasconcelos, 2009). In reference to the indicators used in assessing the construct 'religiosity', we expected that individuals for instance, who are energized by their work, consider their work to be connected with their beliefs, etc would have a lower motivation to quit their jobs. Contrary to our expectation however, the results indicate that accountants who demonstrate higher levels of religiosity have greater intentions to quit their jobs.

While this finding appears curious, it could also mean that most of the respondents at best are extrinsically religious. This is because unlike the intrinsic religious person who sees religion as part of his/her life, the extrinsic religious person sees religion as an end in itself and what benefits to be derived from association with religion. The motivation to leave the organization will, therefore, be high for an extrinsic religious person if the likelihood of getting better offers elsewhere exists. Olowookere et al (2016) suggest extrinsically religious employees see their duties within the organization as transactional and act to safeguard their personal interests and goals. When personal 
needs are not aligned with that of the organization, such employees are likely to quit their job. This result, however, supports the findings of Zafar et al. (2012). Unlike the evidence provided in this study, Hassan et al (2015) found an insignificant relationship between religiosity and turnover intentions. It can thus, be concluded that the exact impact of religiosity on turnover intentions still remained an open question.

In line with the predictions of this study, we find spiritual intelligence to be negatively associated with the turnover intentions of the respondents though not statistically significant ( $\beta=-0.053$ and $p-$ value $=0.278$ ). The negative coefficient in effect suggests that a spiritually intelligent person is less likely to quit the job than the less spiritually intelligent employee. As demonstrated by some studies, there is a strong positive connection between employees' spiritual intelligence and job satisfaction (Koražija, Žižek, \&Mumel, 2016). Employees who are spiritually intelligent are therefore more likely to be satisfied with their job and hence, the motivation to quit will below. Again, Amin Mohamed, Wisnieski, Askar, \& Syed (2004) strongly argue that the commitment of an individual to the organization and workgroup increases when the spiritual dimension of that individual's personality is stronger. This presupposes that a spiritually intelligent person will be more committed to his/her organization and as such, the intention to quit will below. The result supports the stated hypothesis (H4) that spiritual intelligence is negatively associated with turnover intentions.

In terms of the relationship between emotional exhaustion and turnover intention, the study found a positive and highly significant relationship between an emotionally exhausted accountant and turnover intention $(\beta=0.442$ and $p$-value $=0.000)$. This is an indication that an emotionally exhausted employee has a higher tendency of quitting the job. Commonly referred to as the feeling of emotional depletion from a person's job, higher levels of emotional exhaustion have been found to be associated with decreased job satisfaction and increased health symptoms (Laschinger et al., 2004). Thus, reduced job satisfaction and consequently increased turnover intentions are likely to occur when an employee is emotionally exhausted.

Also, the results demonstrate an inverse and highly significant relationship between turnover intentions and job performance of the accountant $(\beta=-0.201$, p-value $=0.000)$. This finding means that when an employee has the intention to quit the organization, his/her performance on the job is very likely to be affected negatively. By implication, the productivity level of an employee with the desire to quit the organization is more likely to be low compared with those who do not have the intention to leave. While studies based on the Expectancy Theory have concluded that poor performance on the job may influence the intention of an employee to quit for fear of being sacked (Zimmerman \& Darnold, 2009), the evidence provided in this study also suggests that turnover intentions are also a good predictor of employees' job performance.

Further, we analyzed the indirect effect of all the exogenous constructs on job performance using turnover intentions as a mediator. Results of this analysis as shown in Table 7 suggest that emotional exhaustion, job satisfaction, and religiosity have a significant association with job performance indirectly through turnover intentions.

We find a negative relationship between emotional exhaustion and job performance which suggests that the job performance of an employee would be low if emotionally exhausted. The positive association between job satisfaction and turnover intention, however, means that employees who are satisfied with their job tend to perform well on the job. Interestingly, a negative relationship was found between religiosity and job performance, an indication that accountants who profess to be religious usually do not perform well on the job. This is in sharp contrast with the findings in prior studies (Weaver \& Agle, 2002) which associate religiosity with improved performance. According to Weaver \& Agle (2002), a religious person imbibes the teachings and norms of the religion, applies the teachings of the religion to work which must enhance performance. The effect of religiosity on performance will, therefore, rest on how a person's religious orientation is brought to bear at the workplace. Within the Ghanaian setting, this finding may not be strange given that serious concerns have been raised over how some religious people spend working hours on faith-based activities. 
Table 7. Results (indirect effects)

\begin{tabular}{|c|c|c|c|c|c|}
\hline & $\begin{array}{l}\text { Original } \\
\text { Sample }\end{array}$ & $\begin{array}{c}\text { Sample } \\
\text { Mean } \\
\text { (Mean) }\end{array}$ & $\begin{array}{l}\text { Standard } \\
\text { Deviation }\end{array}$ & t- Statistics & $\begin{array}{c}\mathrm{p}- \\
\text { Value }\end{array}$ \\
\hline $\begin{array}{l}\text { Emotional Exhaustion->Turnover } \\
\text { intention->Accountant Performance }\end{array}$ & -0.089 & -0.097 & 0.025 & 3.545 & 0.000 \\
\hline $\begin{array}{l}\text { Job satisfaction->Turnover Intention- } \\
\text { >Accountant Performance }\end{array}$ & 0.034 & 0.035 & 0.014 & 2.344 & 0.019 \\
\hline $\begin{array}{l}\text { Organizational commitment->Turnover } \\
\text { Intention->Accountant Performance }\end{array}$ & 0.024 & 0.027 & 0.016 & 1.457 & 0.146 \\
\hline $\begin{array}{l}\text { Religiosity->Turnover Intention-> } \\
\text { Accountant Performance }\end{array}$ & -0.032 & -0.034 & 0.015 & 2.187 & 0.029 \\
\hline $\begin{array}{l}\text { Spiritual Intelligence-> Turnover Intention- } \\
\text { >Accountant Performance }\end{array}$ & 0.011 & 0.014 & 0.011 & 0.949 & 0.343 \\
\hline
\end{tabular}

\section{Conclusions}

The high labour turnover rate in Accounting firms remains one of the critical issues confronting the accounting profession globally (Folami \& Bline, 2012). Apart from the huge cost involved in hiring and training new staff to replace professional and experienced staff who leave the practice, high turnover rate has been linked with reduction expertise in accounting firms and the quality of service provided by accountancy firms impacting negatively on the reputation of auditing firm (Chi et al., 2013; Gertsson et al., 2017; Jannah et al., 2016).

This paper examined the turnover intentions of some selected accountants practicing with audit firms in Ghana. The study focused on the factors that influence the intentions of accountants to quit their immediate jobs and further ascertained if the intentions to quit could be associated with the job performance of accountants. We categorized the factors that influence turnover intentions into 'physical' and 'spiritual' components and tested for their predicted influence using the Partial Least Square based Structural Equation Modelling technique. The study further examined the impact of turnover intentions on job performance of accountants. Our findings suggest that organizational commitment, job satisfaction, emotional exhaustion, and religiosity have a significant association with turnover intentions of accountants. Moreover, the result also demonstrates that turnover intentions could negatively affect the job performance of accountants.

The findings of this study provide some useful insights into the dominant factors that influence the intentions of accountants to quit their job. In particular, the study highlights the role of spiritual intelligence and religiosity on turnover intentions. Given that prior studies have mostly focused on factors that relate to the 'physical' dimension of an individual, this study contributes uniquely to the determinants of turnover intentions by examining factors that relate to the spiritual dimension of an individual as well. Again, we examine a consequence of turnover intentions of employees by highlighting its effect on the job performance of accountants. We provide empirical evidence to show that when the intention to quit one's job is high, it affects the job performance of that individual negatively. The findings of this study thus, provide an important basis for future studies to incorporate the role of spirituality when investigating issues that affect employees, particularly on their turnover intentions.

Author Contributions: Conceptualization, W.D., G.M.Y.O. and S.N.Y.S; methodology, W.D; validation, G.M.Y.O. and S.N.Y.S.; formal analysis, W.D. and G.M.Y.O.; investigation, W.D.; resources, W.D., G.M.Y.O. and S.N.Y.S.; data curation, W.D.; writing-original draft preparation, W.D.; writing-review and editing, G.M.Y.O.; visualization, W.D. and G.M.Y.O.; supervision, G.M.Y.O. and S.N.Y.S.

Funding: This research received no external funding.

Acknowledgments: We would like to thank participants of the 3rd International Conference on Advances in Business and Law at the University of Dubai, for their insightful comments that helped in shaping this paper. 
Conflicts of Interest: The authors declare no conflict of interest.

\section{References}

Ahmed, R. A. \& Abdullah, H. A. (2016). A proposed framework of audit fees determinants in the Kurdistan region. European Journal of Business and Management, 8(12).

Aghdasi, S., Kiamanesh, A. R., \&amp; Ebrahim, A. N. (2011). Emotional intelligence and organizational commitment: Testing the mediatory role of occupational stress and job satisfaction. Procedia - Social and Behavioral Sciences, 29(2010), 1965-1976.

Amin Mohamed, A., Wisnieski, J., Askar, \& Syed. (2004). Towards a theory of spirituality in the workplace. Competitiveness Review: An International Business Journal, 14(1/2), 102-107.

Armstrong, M. (2006). A handbook of human resource management practice, tenth edition, Kogan Page Publishing, London, 264

Anwar, M. A., \& Opusman-Gani, A. M. (2015). The effects of spiritual intelligence and its dimensions on organizational citizenship behavior. Journal of Industrial Engineering and Management, 8(4), 1162-1178.

Ashmos, D.P. \&Duchon, D. (2000), Spirituality at work: A conceptualization and measure, Journal of Management Inquiry, 9(2), 134-45.

Astrachan, C. B., Patel, V. K., \& Wanzenried, G. (2014). A comparative study of CB-SEM and PLS-SEM for theory development in family firm research. Journal of Family Business Strategy, 5(1), 116-128.

Aydogdu, S. (2011). An empirical study of the relationship between job satisfaction, organizational commitment, and turnover intention. International Review of Management and Marketing, 1(3), 43-53.

Babakus, E., Yavas, U., \& Karatepe, O. M. (2008). The effects of job demands, job resources and intrinsic motivation on emotional exhaustion and turnover intentions: A study in the Turkish hotel industry. International Journal of Hospitality \& Tourism Administration, 9(4), 384-404.

Bergin, A. E. (1994). Religious Lifestyles and Mental Health, 69-93. Springer, New York, NY.

Campbell, J. W., Im, T., \& Jisu, J. (2014). Internal efficiency and turnover intention: Evidence from local government in South Korea. Public Personnel Management, 43(2), 259-282.

Chi, W., Hughen, L., Lin, C. J., \&Lisic, L. L. (2013). Determinants of audit staff turnover: Evidence from Taiwan. International Journal of Auditing, 17(1), 100-112.

Chong, V. K., \& Monroe, G. S. (2013). The impact of the antecedents and consequences of job burnout on junior accountants' turnover intentions: a structural equation modeling approach. Accounting and Finance.

Chong, V. K., \& Monroe, G. S. (2015). The impact of the antecedents and consequences of job burnout on junior accountants' turnover intentions: a structural equation modeling approach. Accounting $\mathcal{E}$ Finance, 55(1), 105132.

Cohen, A. (2003). Multiple commitments in the workplace: An integrative approach. Psychology Press.

Ducharme, L. J., Knudsen, H. K., \& Roman, P. M. (2007). Emotional exhaustion and turnover intention in human service occupations: The protective role of co-worker support. Sociological Spectrum, 28(1), 81-104.

Financial Reporting Council (FRC) (2006), 'Promoting audit quality', Discussion Paper, London: FRC.

Ferreira Vasconcelos, A. (2009). Intuition, prayer, and managerial decision-making processes: a religion-based framework. Management Decision, 47(6), 930-949.

Folami, L., \&amp; Bline, D. (2012). The relationship among job satisfaction, task complexity and organizational context in public accounting, 8(4), 207-224.

Fogarty, T. J., \&amp; Kalbers, L. P. (2006). Internal auditor burnout: an examination of behavioral consequences. Advances in Accounting Behavioural Research.

Fornell, C. and Larcker, D.F. (1981), Structural equation models with unobservable variables and measurement error: algebra and statistics, Journal of Marketing Research, 18(3), 382-388.

Goldstein, D. (2014). Recruitment and Retention : Could emotional intelligence be the answer. Journal of New Business Ideas ETrends, 12(2), 14-21.

George, M. (2006). Practical application of spiritual intelligence in the workplace. Human Resource Management International Digest, 14(5), 3-5.

Gertsson, N., Sylvander, J., Broberg, P., \& Friberg, J. (2017). Exploring an audit assistant's decision to leave the audit profession. Managerial Auditing Journal, 32(9), 879-898.

Hair, J. F., Ringle, C. M., \&amp; Sarstedt, M. (2013). Partial least squares structural equation modeling: rigorous applications, better results, and higher acceptance. Long Range Planning, 46(1-2), 1-12. 
Hassan, N., Mohammad, A., Mohd, F., Rozilah, A., \& Ali, S. (2015). Religiosity perceptions and employee turnover intention in Malaysia. International Journal of Social Science and Humanity, 5(1), 120-125.

Halbesleben, J. R., \& Buckley, M. R. (2004). Burnout in organizational life. Journal of Management, 30(6), 859-879.

Hiltebeitel, K. M., \&Leauby, B. A. (2001). Migratory patterns of entry-level accountants. The CPA Journal, 71(4), 54. Hoppock, R. (1935). Job satisfaction. New York: Harper

Ijigu, A. W. (2015). The effect of selected human resource management practices on employees' job satisfaction in Ethiopian public banks. Emerging Markets Journal, 5(1), 1-16

Jannah, B. S., Baridwan, Z., \&amp; Hariadi, B. (2016). The determinant of Auditors' Turnover Intention from Public Accounting Firm. Imperial Journal of Interdisciplinary Research, 2(2), 537-547.

Jaramillo, F., Mulki, J. P., \& Solomon, P. (2006). The role of ethical climate on salesperson's role stress, job attitudes, turnover intention, and job performance. Journal of Personal Selling \& Sales Management, 26(3), 271-282.

King, D. (2008). Rethinking claims of spiritual intelligence: A definition model and measure. Thesis, Trent University.

Koražija, M., Žižek, S. Š., \&Mumel, D. (2016). The relationship between spiritual intelligence and work satisfaction among leaders and employees. Našegospodarstvo/Our economy, 62(2), 51-60.

Kutcher, E. J., Bragger, J. D., Rodriguez-Srednicki, O., \& Masco, J. L. (2010). The role of religiosity in stress, job attitudes, and organizational citizenship behavior. Journal of Business Ethics, 95(2), 319-337.

Lambert, E., \& Paoline III, E. A. (2010). Take this job and shove it: An exploratory study of turnover intent among jail staff. Journal of Criminal Justice, 38(2), 139-148.

Laschinger, H. K., Almost, J., Purdy, N., \& Kim, J. (2004). Predictors of nurse managers' health in Canadian restructured healthcare settings. Nursing Leadership (Toronto, Ont.), 17(4), 88-105.

Lim, A. J. P., Loo, J. T. K., \& Lee, P. H. (2017). The impact of leadership on turnover intention: the mediating role of organizational commitment and job satisfaction. Journal of Applied Structural Equation Modelling, 1(1), 2741.

Liu, D., Mitchell, T. R., Lee, T. W., Holtom, B. C., \&Hinkin, T. R. (2012). When employees are out of step with coworkers: How job satisfaction trajectory and dispersion influence individual and unit-level voluntary turnover. Academy Of Management Journal, 55(6), 1360-1380.

Medina, E. (2012). LizMedina_QMSS_Thesis.

McGhee, P., \& Grant, P. (2008). Spirituality and ethical behavior in the workplace: Wishful thinking or authentic reality. Electronic Journal of Business Ethics and Organisation Studies, 13(2), 61-69

Mokhlis, S. (2006). The effect of religiosity on shopping orientation: an exploratory study in Malaysia. Journal of American Academy of Business, 9(1), 64-74.

Mor Barak, M. E., Nissly, J. A., \& Levin, A. (2001). Antecedents to retention and turnover among child welfare, social work, and other human service employees: What can we learn from past research? A review and metanalysis. Social service review, 75(4), 625-661.

Neck, C. P., \&amp; Milliman, J. F. (1994). Thought Self-leadership, 9(6), 9-16.

Olowookere, E. I., Adekeye, O. A., Adejumo, G. O., Agoha, B. C., \&Sholarin, M. A. (2016).Influence of religiosity on turnover intention: empirical evidence from selected employees in Lagos and Ogun States. IFE Psychological: An International Journal, 24(2), 132-138.

Maslach, C., Schaufeli, W. B., \& Leiter, M. P. (2001). Job burnout. Annual review of psychology, 52(1), 397-422.

Maslach, C., Jackson, S. E., Leiter, M. P., Schaufeli, W. B., \& Schwab, R. L. (1986). Maslach burnout inventory, 21, 3463-3464.

Mowday, R. T., Porter, L. W., \&Dubin, R. (1974). Unit performance, situational factors, and employee attitudes in spatially separated work units. Organizational Behavior and Human Performance, 12(2), 231-248.

Nunnally, J.C. (1978), Psychometric Theory, McGraw-Hill, New York, NY

Owusu, G. M. Y., Obeng, V. A., Ofori, C. G., Ossei Kwakye, T., \& Bekoe, R. A. (2018). What explains the student's intentions to pursue a certified professional accountancy qualification? Meditari Accountancy Research, 26(2), 284-304.

Porter, L. W., Steers, R. M., Mowday, R. T., \& Boulian, P. V. (1974). Organizational commitment, job satisfaction, and turnover among psychiatric technicians. Journal of Applied Psychology, 59(5), 603.

Pradana, A., \& Salehudin, I. (2013). Role of work overload toward turnover intention among newly hired public accountants. Munich Personal RePEc Archive, (54342), 1-16. 
Purnamasari, P., \& Amaliah, I. (2015). Fraud prevention: Relevance to religiosity and spirituality in the workplace. Procedia-Social and Behavioral Sciences, 211, 827-835.

Rahman, W., Rahman, H., \& Ali, F. (2015). Interrelationship of employee development, organizational commitment, job satisfaction and their impact on turnover intentions. City University Research Journal, 5(2), 301-314

Ramalho Luz, C. M. D., Luiz de Paula, S., \& de Oliveira, L. M. B. (2018). Organizational commitment, job satisfaction and their possible influences on intent to turnover. Revista de Gestão, 25(1), 84-101.

Sauerwein, J. (2017). The intersection of religiosity, workplace spirituality and ethical sensitivity in practicing accountants. Journal of Religion and Business Ethics, 3(2), 4.

Schwepker Jr, C. H. (2001). Ethical climate's relationship to job satisfaction, organizational commitment, and turnover intention in the salesforce. Journal of Business Research, 54(1), 39-52.

Seligman, M. (2002). Authentic happiness using the new positive free press psychology to realize your potential for lasting fulfillment, New York

Sheldon, M. E. (1971). Investments and involvements as mechanisms producing commitment to the organization. Administrative science quarterly, 16(2).

Tarigan, V., \& Ariani, D. W. (2015). Empirical study relations job satisfaction, organizational commitment, and turnover intention. Advances in Management EApplied Economics, 5(2), 21-42.

Tnay, E., Othman, A. E. A., Siong, H. C., \& Lim, S. L. O. (2013). The influences of job satisfaction and organizational commitment on turnover intention. Procedia-Social and Behavioral Sciences, 97, 201-208.

Vaughan, F. (2002). What is spiritual intelligence? Journal of humanistic psychology, 42(2), 16-33.

Weaver, G. R., \& Agle, B. R. (2002). Religiosity and ethical behavior in organizations: A symbolic interactionist perspective. Academy of Management Review, 27(1), 77-97.

Wallace, J., \& Gaylor, K. P. (2012). A study of the dysfunctional and functional aspects of voluntary employee turnover. SAM Advanced Management Journal, 77(3), 27.

Walsh, J. P., Ashford, S. J., \& Hill, T. E. (1985). Feedback obstruction: The influence of the information environment on employee turnover intentions. Human Relations, 38(1), 23-46.

Wolman, RN. (2001).Thinking with your soul: spiritual intelligence and why it matters. New York: Harmony Books.

Yücel, I. (2012). Examining the relationships among job satisfaction, organizational commitment, and turnover intention: An empirical study. International Journal of Business and Management, 7, 44-58.

Zafar, R., Altaf, M., Bagram, M. M. M., Hussain, H., Tabassum Riaz, A. H., Nadim, M., \& Chaudhry, M. S. (2012). Religiosity, as a determinant of turnover intention: An exploratory study. The Journal of Commerce, 4(4), 1-8.

Zimmerman, R. D., \& Darnold, T. C. (2009). The impact of job performance on employee turnover intentions and the voluntary turnover process: A meta-analysis and path model. Personnel Review, 38(2), 142-158.

(C) 2020 by the authors. This paper is an open-access article distributed under the terms and conditions of the Creative Commons Attribution (CC BY) license (http://creativecommons.org/licenses/by/4.0/). 